\title{
The impact of cathelicidin, the human antimicrobial peptide LL-37 in urinary tract infections
}

Ibrahim H. Babikir ${ }^{1,4^{*}}$, Elsir A. Abugroun ${ }^{2}$, Naser Eldin Bilal ${ }^{3}$, Abdullah Ali Alghasham ${ }^{4}$ Elmuataz Elmansi Abdalla ${ }^{4}$ and Ishag Adam $^{4}$

\begin{abstract}
Background: The defense mechanisms of the urinary tract are attributed mainly to the innate immune system and the urinary tract urothelium which represent the first line of defense against invading pathogens and maintaining sterility of the urinary tract. There are only a few publications regarding cathelicidin (LL-37) and a urinary tract infection (UTI). This study was done to investigate the plasma and urine levels of human LL-37 in patients with UTI.

Methods: A case-control study was conducted at Omdurman Hospital, Sudan during the period from August 2014 to May 2017. The cases were patients with confirmed UTI and the controls were healthy volunteers without UTI. Sociodemographic and clinical data were obtained from each participant using questionnaires. Urine cultures and antimicrobial susceptibility were tested. Plasma and urine levels of LL-37 were determined using an enzymelinked immunosorbent assay (ELISA) kit. SPSS (version 16.0) was used for analyses.

Results: Cases and controls (87 in each arm) were matched according to their basic characteristics. Compared with controls, the median (inter-quartile) LL-37 level in plasma [2.100 (1.700-2.700) vs. $1.800(1.000-2.200) \mathrm{ng} / \mathrm{ml}, P=0.002]$ and in urine $[0.900(0.300-1.600)$ vs. $0.000(0.000-1.000) \mathrm{ng} / \mathrm{mg}$ creatinine, $P<0.001]$ was significantly higher in cases. There was no significant difference in the median plasma [2.1 (1.7-2.9) vs. $2.000(1.700-2.400) \mathrm{ng} / \mathrm{ml}, P=0.561]$ and urine $[0.850(0.275-2.025)$ vs. $0.900(0.250-1.350) \mathrm{ng} / \mathrm{mg}$ creatinine, $P=0.124]$. The uropathogenic Escherichia coli (UPEC) was the predominant isolate, $n=38$ (43.7\%). LL-37 levels between the E. coli isolates and the other isolated organisms. There was no significant correlation between plasma and urine LL-37 levels $(r=0.221)$, even when the data of the cases were analyzed separately.

Conclusion: LL-37 is notably increased among patients with UTI compared with normal control subjects. Severity of UTI increases the levels of LL-37. The increased level was not only in the patient's urine, but has also been observed in the patient's plasma. Detection of increased levels of LL-37 could help to differentiate subjects with suspected UTI. Accordingly, LL-37 could act as a good marker for diagnosing UTIs.
\end{abstract}

Keywords: Urinary tract infections, Cathelicidin, LL-37, Antimicrobial peptide, Vitek 2 System, Uropathogenic E. coli, Sudan

\footnotetext{
* Correspondence: almakibrahim@hotmail.com

${ }^{1}$ College of Medical Laboratory Sciences, Microbiology Department,

University of Khartoum, Khartoum, Sudan

${ }^{4}$ College of Medicine, Qassim University, Buraydah, Qassim, Kingdom of Saudi

Arabia

Full list of author information is available at the end of the article
}

(c) The Author(s). 2018 Open Access This article is distributed under the terms of the Creative Commons Attribution 4.0 International License (http://creativecommons.org/licenses/by/4.0/, which permits unrestricted use, distribution, and reproduction in any medium, provided you give appropriate credit to the original author(s) and the source, provide a link to the Creative Commons license, and indicate if changes were made. The Creative Commons Public Domain Dedication waiver (http://creativecommons.org/publicdomain/zero/1.0/) applies to the data made available in this article, unless otherwise stated. 


\section{Background}

Urinary tract infection (UTI) is a major health problem as it is one of the most common bacterial infections. The predominant causal organism is Escherichia coli (E. coli). The innate immune response to urinary pathogens can both control and predispose to subsequent recurrence of UTIs, at least for a significant proportion of patients [1, 2].

Increasing bacterial resistance to common antibiotics has been a growing public health concern [2,3]. Emergence of multi-drug resistant microbes was seen as early as the 1950 s as the result of antibiotic misuse or overuse $[4,5]$.

Although, there are many routes by which microbes can reach the urinary tract and the kidneys $[6,7]$, the defensive mechanisms of the innate immune system, in addition to the urinary tract urothelium, represent the first line of defense against these invading pathogens helping the urinary tract to remain sterile [1]. Dysfunction in these immune mechanisms may lead to acute disease, massive infection and tissue destruction, which may turn the 'friendly' host defense into troublesome and disturbing enemies and give rise to disease, in addition to long-term complications such as hypertension and chronic kidney disease [1, 8]. Progression to renal scarring and permanent impairment of renal function and tissue destruction may occur $[9,10]$.

In mammals, several defense mechanisms guard against the threat of infection, including the innate immune response and physical factors, such as urine flow, $\mathrm{pH}$, and ionic composition together with expression of natural antimicrobial peptides (AMPs) [1, 8]. AMPs are considered the first line of innate immune defense against invading pathogens as they play a fundamental role in protection from prokaryotes [11]. At least two distinct groups of AMPs have been reported; the defensins and cathelicidin. In contrast to the multiple defensins (alpha, beta, and gamma), to date, only one cathelicidin has been found in humans [11-13]. The gene product is synthesized as a propeptide and is referred to as human cationic antimicrobial peptide-18 (hCAP-18/LL-37). hCAP-18 is the precursor molecule and its molecular weight is $18 \mathrm{Kd}$. In various tissues, hCAP-18 is cleaved by proteases to form two parts; the N-terminal (cathelin) and C-terminal part. The latter is further cleaved enzymatically to produce a 37 amino acid peptide which starts with two leucines, hence the name LL-37; LL-37 is considered the main biologically active broad spectrum antimicrobial agent $[14,15]$.

Due to the cationic nature of LL-37, an amphipathic $\alpha$ helical peptide, it has broad spectrum antimicrobial activity against bacteria, fungi, viruses, and parasites, but notably, shows low toxicity to human cells. During inflammation, it has been identified as a potent chemoattractant for innate and adaptive immune cells $[9,16]$. LL-37 has been shown to neutralize lipopolysaccharides (LPS), which are endotoxins of Gram-negative bacteria that are released upon cell death, by binding to them with high affinity $[17,18]$. Additionally, LL-37 has been shown to inhibit the association of
LPS with its receptor, suppressing LPS-induced apoptosis of endothelial cells [19], and to block the effects of flagellin and lipoteichoic acid on dendritic cells [20].

Attention and interest concerning endogenous defense has been stimulated by increasing concern regarding antimicrobial overuse. Enhancement of natural mechanisms will be an exciting novel therapeutic avenue in the management of UTIs [1, 21]. LL-37 has potent, direct antimicrobial activity at minimum inhibitory concentrations (MIC) than synthetically and traditionally used antimicrobial agents [22, 23]. Moreover, these peptides have potential activity against multiple drug-resistant microbes [23, 24]. Thus, AMPs or their derivatives potentially represent a new category of antimicrobial agents [23, 24].

Production of cathelicidin peptides by blood cells [4] and by the epithelial cells in the urothelium mucous membranes has been proposed as a natural innate immune response to maintain a normal sterile urinary tract and represents a candidate for a novel class of antimicrobials [25, 26]. Despite the mechanisms of the innate immune response, bacteria still cause UTIs. In contrast, involvement of the adaptive immune response to UTIs is poorly understood. However, it has been suggested that secretory immunoglobulin A ( $\operatorname{IgA}$ ) antibodies inhibit bacterial colonization by lowering bacterial adherence to the mucosa antibodies during UTIs, even though serum production of antibodies is characteristically difficult to detect in UTIs [27].

To our knowledge, this is the first study on cathelicidin in Sudan. However, there are a few globally published data on LL-37 and UTI [2, 8, 21, 26]. The current study was conducted to investigate plasma and urinary levels of LL-37 in patients with (culture positive) UTI compared with healthy volunteers, and to add to the previous research on UTI in Sudan [28, 29].

\section{Methods}

This is a case-control study was conducted at Omdurman Hospital, Sudan, during the period June-September 2014. Institutional review board approval was obtained from the Faculty of Medical Laboratory Sciences Research Ethics Review Board, University of Khartoum, Sudan. A signed written informed consent was obtained from all subjects or from the parents or guardians in case of the participants under the 16 years of age. Sociodemographic and clinical data were obtained from each participant using structured pre-tested questionnaires.

\section{Study setting and population}

Consecutive patients with UTI symptoms who attended the referral clinic were approached to participate in the study. Cases were (males and females) those who met the inclusion criteria; signs and symptoms of UTI, willingness (the participant agreed to participate), and no other health problem or underlying disease. The controls were apparently 
healthy volunteers with no current or previous history of UTIs. Diabetic patients, pregnant women or subjects with anatomical or functional abnormalities of the urinary tract or subjects with underlying diseases were excluded from both the case and control groups.

For cases, an initial survey covered medical history, demographics and symptoms (dysuria, frequency, urgency, lower abdominal or suprapubic pain, fever, costovertebral tenderness [flank pain], nausea and vomiting), in addition to their culture positive results.

\section{Collection and processing specimens}

Paired Blood and urine samples were collected from each participant. Under a septic technique, $5 \mathrm{ml}$ of blood was withdrawn in Ethylene-diamine-tetra-acetic acid (EDTA) anticoagulant tube. The blood samples were directly tested for complete blood count (CBC) using Sysmex KX-21 N, and then carefully centrifuged $\left(1500 \times \mathrm{g}\right.$ at $4{ }^{\circ} \mathrm{C}$ for $15 \mathrm{~min}$ ) to separate plasma. Plasma specimens were stored at $-80^{\circ}$ C. For urine specimens all participants were asked to provide a midstream urine sample according to the cleancatch procedure. Urine Samples were collected using a sterile screw capped wide mouth container and processed immediately. In the medical laboratory each urine sample was divided into two; the first half was stored at $-80{ }^{\circ} \mathrm{C}$ and the second half was immediately inoculated on standard culture media. A standard quantitative $(1 \mu \mathrm{L}$ and $10 \mu \mathrm{L})$ loop was used to inoculate urine samples on to Cysteine Lactose Electrolyte Deficient (CLED) agar, MacConkey's and Blood Agar (Oxoid, Basingstoke, UK). Plates were incubated aerobically at $35-37^{\circ} \mathrm{C}$ for $24 \mathrm{~h}$ and the outcome was judged as significant/non-significant growth, or contaminated (discarded). The rest of urine was centrifuged $(1500 \times \mathrm{g}$ for $5 \mathrm{~min}$ ) to prepare urine debris for direct microscopic examination for Red Blood Cells (RBCs), pus cells (leukocyturia), epithelial cell count, casts, crystals and parasitic infection if present. In the normal urine sediment a few count of RBCs, pus cells $(0-5$ per high power field, HPF) and epithelial cells may present. Epithelial cell count reported as "few," "moderate," or "many" per low power field (LPF).

A portion of the urine specimens was used for dipstick test rapid response urinalysis Reagent Strips (Combi-Screen PLUS, Roche, USA). For the control participants, nitrite and leukocyte esterase positivity were considered as a positive indicator for active infection and those were excluded from the study. When the patient had a nitrite and leukocyte esterase dipstick negative results, UTI confirmed by urine culture examination.

LL-37 analysis for both plasma and urine samples was performed using ELISA kit (HK321-02 HycultBiotech, Gmbh, Germany) as described elsewhere [30-32].

The bacterial identification and the antimicrobial susceptibility were done by using the fully automated VITEK-2 Compact System (see below).

\section{Measurements}

Colony counting is the numerical cut-off estimation for the number of viable bacteria in a milliliter of uncentrifuged urine; it is a quantitative estimation that enables us to differentiate the true bacteriuria from urethral or vulval contamination, which may occur during collection of mid-stream or "clean-catch" urine [26, 28, 29]. Multiplication of microbes in the urinary system is defined by the presence of more than $10^{5} \mathrm{CFU} / \mathrm{ml}$ of urine, which is significantly diagnostic of UTI $[26,28,30]$. Significant UTI was defined as urine culture plates showing $\geq 10^{5}$ colony-forming units $(\mathrm{CFU}) / \mathrm{mL}$ freshly voided urine. Referring to the cut-off of $10^{5} \mathrm{CFU} / \mathrm{ml}$, a positive urine culture was identified as $\geq 10^{5} \mathrm{CFU} / \mathrm{ml}$ of one to two organisms from a clean-catch specimen $[28,29]$.

The bacterial identification and the antimicrobial susceptibility were done by using the fully automated VITEK-2 Compact System. Prior application of Vitek system clinically significant isolates were sub-cultured for purity and inoculated on specific plates (nutrient agar or blood agar), then incubated aerobically at 35$37{ }^{\circ} \mathrm{C}$ in $5 \% \mathrm{CO}_{2}$. Isolated bacteria were differentiated according to their colonial morphology and gram stain. After overnight incubation, the bacterial colonies were used to prepare a standardized saline inoculum for the appropriate VITEK identification (ID) card. For identification of bacteria, special ID and sensitivity (AST) cards (BioMérieux) were used. Gram positive ID card: [GP Reference 21 342], gram Positive sensitivity card: [GP/ AST-580 Reference 22 233], gram negative ID card: [GN Reference 21341 ], and gram negative sensitivity card: [AST-N291 Reference 415 062]. All methods and techniques were conducted as described by the manufacturer. The VITEK-2 ID and AST cards were logged and loaded into the VITEK-2 Compact system. The VITEK-2 Compact system automatically reported and printed the results through software 06.01 .

A total sample size of 87 participants in each arm of the study was calculated using a formula for the difference in the mean of the proposed variables (plasma and urine LL-37) that would provide $80 \%$ power to detect a $5 \%$ difference at $\alpha=0.05$ and which assumed that $10 \%$ of participants might not have complete data.

The urinary LL-37 levels was performed using [human LL-37 ELISA Kit $\left(\mathrm{Hycult}^{\circ}\right)$ ] according to the manufacturer procedure. Final concentrations were based on a standard curve and are shown in $\mathrm{ng} / \mathrm{ml}$.

For normalization we divided a urine LL-37 concentration in " $\mathrm{ng} / \mathrm{ml}$ " by creatinine in " $\mathrm{mg} / \mathrm{ml}$ " to determine normalized LL-37 in "ng/mg creatinine" i.e. "ng LL-37/ mg creatinine".

The urinary creatinine (Ucr) levels were analyzed as described previously (32), briefly, we measured urinary creatinine colorimetrically by diluting urine samples $1: 20$ 
in dilution buffer from the Creatinine Assay Kit (Creatinine-J. REF. 100,111, SPINREACT, S.A./SAU-Ctra. Santa Coloma, 7 E-17176 SANT ESTEVE DE BASGirona, Spain). Urinary creatinine calculated in $\mathrm{mg} / \mathrm{ml}$ based on a standard curve. The normalized levels of LL37 were expressed as "ng LL-37/mg creatinine" ratios. Creatinine equation formula [LL-37/UCrX100].

\section{Statistics}

SPSS for window (version 16.0) was used for analyses. Students'-test and $\chi^{2}$ were used to compare the continuous variables (when normally distributed) and proportions between the cases and controls, respectively. The levels of LL-37 were not normally distributed and were compared between the cases and controls by MannWhitney $U$ test. Logistic and linear regression was performed with UTI (logistic) and log of LL-37 level (linear); these were the dependent variables. Spearman correlation (non-parametric) was performed between the plasma and urine levels. $P<0.05$ was considered statistically significant.

\section{Results}

During the study period, 197 subjects were initially screened, among these $23(11.7 \%)$ were excluded because they had incomplete data, or, not enough samples. The two groups (87 in each arm) which were enrolled were matched in their basic characteristics, as shown in Table 1. There were $38(43.7 \%)$ and 46 (52.9\%), $P=0$. 288 males in the case and control groups, respectively.

The common organisms isolated from the 87 cases were Escherichia coli (38, 43.7\%), Klebsiella pneumoniae (16, 18.4\%), Enterobacter cloacae (4, 4.6\%), Pseudomonas aeruginosa (4, 4.6\%), Proteus mirabilis (3, 3.4\%), Acinetobacter baumannii (3, 3.4\%), Acinetobacter lwoffii (3, 3.4\%), Klebsiella oxytoca (2, 2.3\%), Morganella morganii (2, 2.3\%), Pantoea agglomerans (3, 3.4\%), Pseudomonas luteola (2, $2.3 \%)$, Enterococcus faecalis (2, 2.3\%), Enterococcus faecium (2, 2.3\%), Staphylococcus aureus (2. 2.3\%), Staphylococcus saprophyticus $(1,1.1 \%)$.

Compared with the control group, median (inter-quartile) plasma [2.100 (1.700-2.700) vs. $1.800(1.000-2.200) \mathrm{ng} / \mathrm{ml}$,

Table 1 Comparing number (\%) of age and gender between controls and cases with urinary tract infection

\begin{tabular}{llll}
\hline Gender & Cases & Controls & P. value \\
\hline Male & $46(52.9)$ & $38(43.7)$ & 0.225 \\
Female & $41(47.1)$ & $49(56.3)$ & \\
Age groups & & & \\
$\quad$ Children & $18(20.7)$ & $15(17.3)$ & 0.856 \\
$\quad$ Adults & $43(49.4)$ & $45(51.7)$ & \\
Elderly & $26(29.9)$ & $27(31.0)$ & \\
\hline
\end{tabular}

$P=0.002]$ and in urine $[0.900(0.300-1.600)$ vs. 0.000 (0.000-1.000) ng/mg creatinine, $P<0.001$ ] LL-37 levels were significantly higher for the cases group (Fig. 1a and b).

There was a significant difference in the plasma and urine levels of LL-37 between males and females when the data for cases and controls were analyzed as a whole or when the data of the controls were analyzed separately. Moreover, in the male cases group, the LL-37 plasma [2.000 (1.675$2.325)$ vs. $1.800(0.600-2.200) \mathrm{ng} / \mathrm{ml}, P<0.001]$ and urine [0.650 (0.100-1.250) vs. $0.000(0.000-0.250)$ ng/mg creatinine, $\mathrm{P}<0.001]$, However, the females had significantly higher median (inter-quartile) plasma LL-37 levels [2.2 (1.800-3.050 vs. $1.900(1.350-2.200) \mathrm{ng} / \mathrm{ml}, P=0.001]$ and urine $[0.900(0.7000-2.050)$ vs. $0.000(0.000-0.600) \mathrm{ng} / \mathrm{mg}$ creatinine, $\mathrm{P}<0.001$ ] LL-37 levels were significantly higher for the female cases group (Fig. 1a and b).

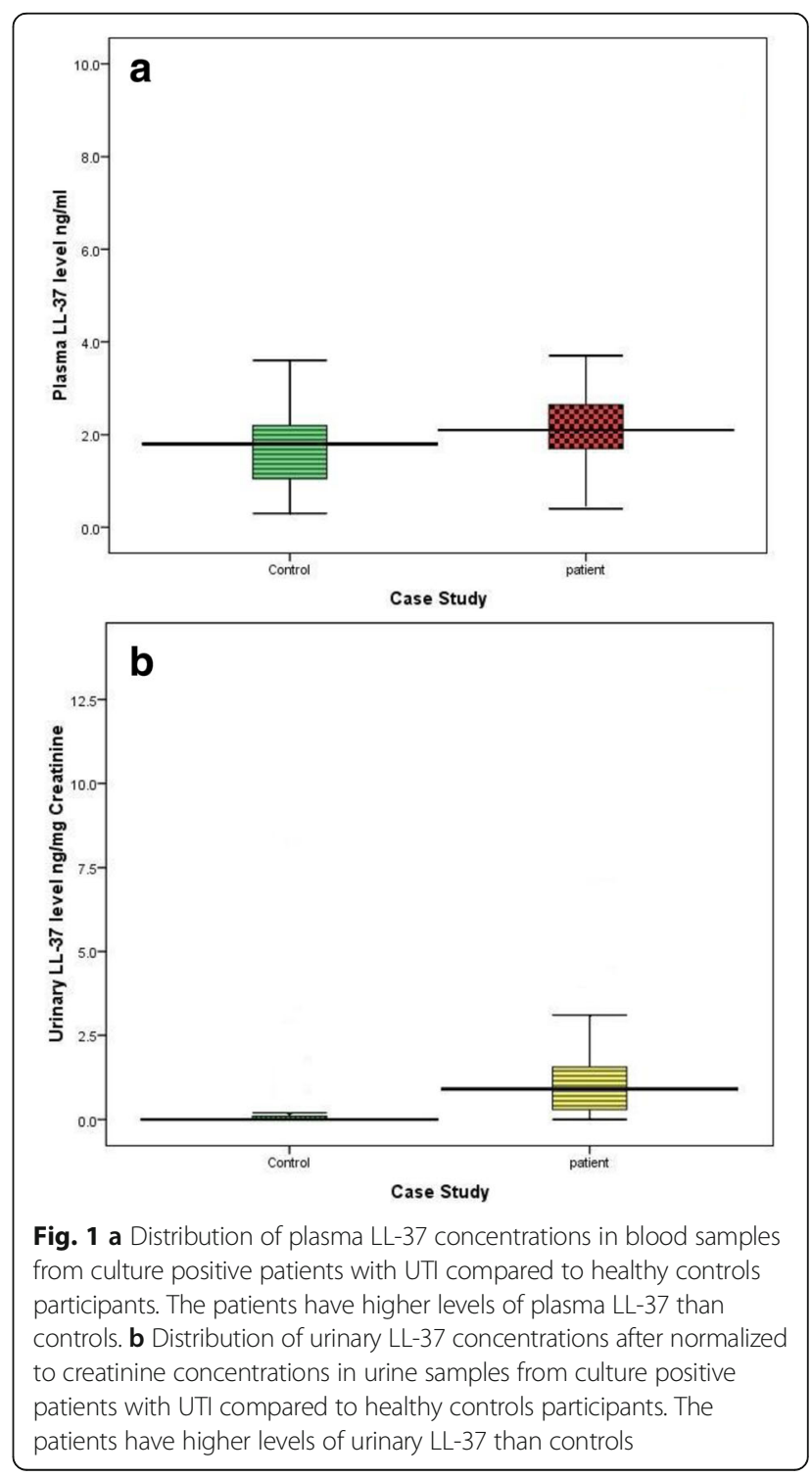


Compared plasma and urine levels of LL-37 between males and females group, in consideration to the severity of (upper and lower) UTI, median (inter-quartile) plasma [2.000 (1.675-2.325) vs. $2.200(1.800-3.050) \mathrm{ng} /$ $\mathrm{ml}, P=0.002]$ and urine $[0.650(0.100-1.250)$ vs. 0.900 (0.7000-2.050)] $\mathrm{ng} / \mathrm{mg}$ creatinine, However, there were no significant difference between males and females in urinary LL-37 levels, a considerable increase of plasma LL-37 was detected among the females (Fig. 2).

There was no significant difference in the median (interquartile) plasma [2.1 (1.7-2.9) vs. $2.000(1.700-2.400) \mathrm{ng} /$ $\mathrm{ml}, P=0.561]$ and urine $[0.850(0.275-2.025)$ vs. 0.900 $(0.250-1.350) \mathrm{ng} / \mathrm{mg}$ creatinine, $P=0.102]$ LL-37 levels between the $E$. coli isolates and the other isolated organisms.

There was no significant correlation between the plasma and urine level $(r=0.221)$, even when the data of the cases were analyzed separately. According to linear regression analysis, UTI was significantly associated with high plasma and urinary levels of LL-37 Table 2.

\section{Discussion}

The main findings of the current study were the significantly higher levels of both plasma and urinary LL37 levels among patients with UTI compared with those of controls. Our findings are in agreement with recent reports $[8,33]$. Nielsen et al., reported that, the urinary LL-37 levels were significantly higher during infection than post infection, yet the post infection
LL-37 levels were significantly lower in patients with UTI than those of controls [32]. In another setting, Ovunç Hacıhamdioglu D. et al., showed no significant differences in the levels of urinary LL-37 between the children with UTI and the control groups [34].

In previous reports, the activity and functions of some other biomarker compounds have been mentioned, as for example, the antibacterial properties of the epithelial cells plays a role in the innate immunity of the urinary tract [35]. Moreover, it has been shown that some factors of innate immunity (Tamm-Horsfall protein) interfere with bacterial adherence [36], sIgA antibodies inhibit bacterial colonization [37], and inhibit bacterial growth [38] or directly kill uropathogens $[39,40]$; the bacterial attachment results in exfoliation of host bladder epithelial cells [41].

Similar results were shown by Chromek et al. who studied urinary cathelicidin from both healthy children and children with UTIs and observed that cathelicidin is constitutively expressed in the urinary tract. Milan Chromek and his colleges mentioned that, the direct contact with microbes induces urinary epithelial cells to substantially increase production and secretion of cathelicidin, protecting the urinary tract from microbial adherence. Cathelicidin deficiency predisposes to urinary infections as it has been shown that mice which are CRAMP-deficient (Camp-/-) are more susceptible to UTI than CRAMP-producing $(\mathrm{Camp}+/+)$ mice [31].

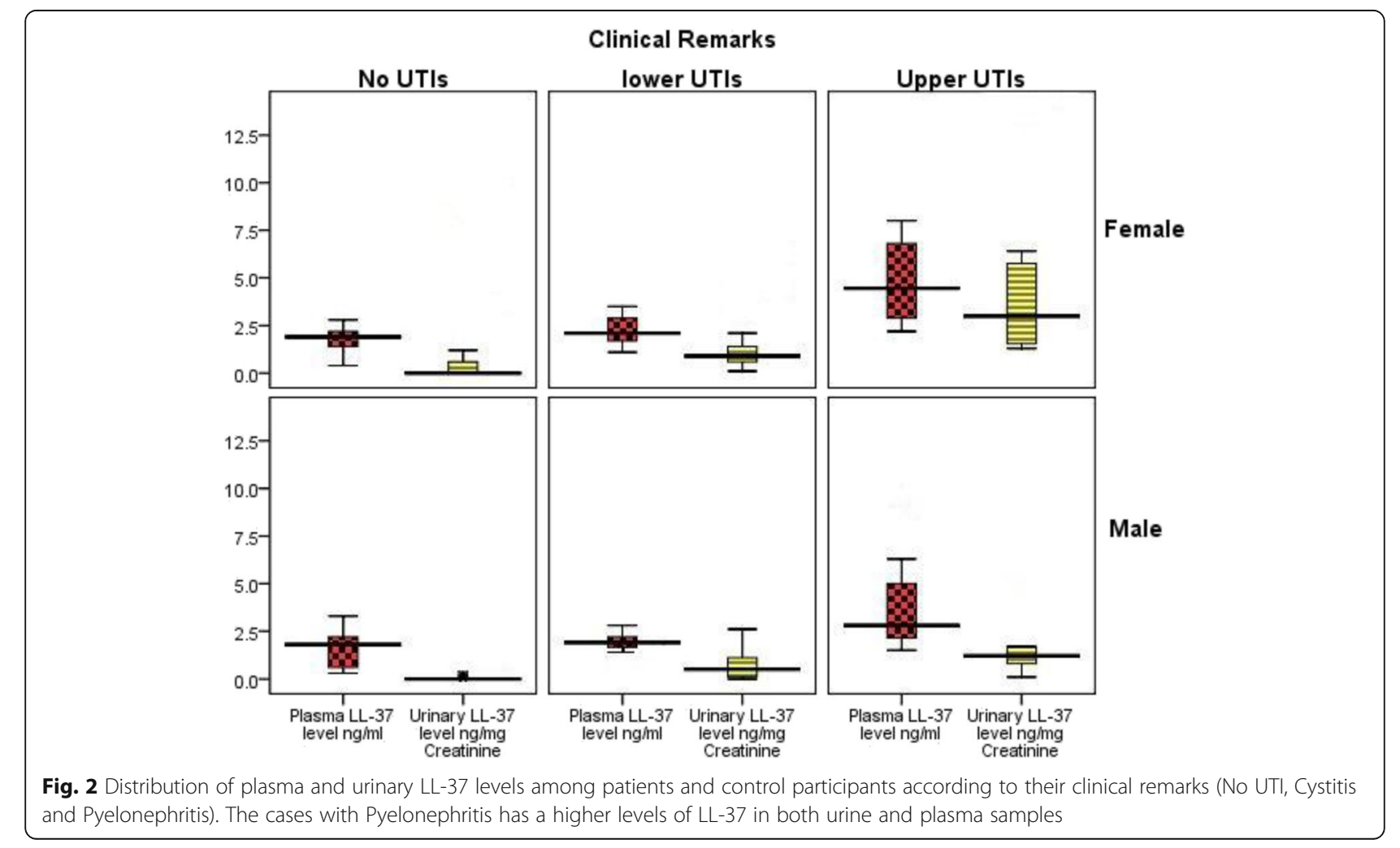


Table 2 Linear regression analysis of associated factors, log of plasma and urine LL-37 levels

\begin{tabular}{|c|c|c|c|c|c|c|}
\hline \multirow[t]{2}{*}{ Variable } & \multicolumn{3}{|c|}{$\begin{array}{l}\text { Log of plasma LL-37 } \\
(\mathrm{ng} / \mathrm{ml})\end{array}$} & \multicolumn{3}{|c|}{$\begin{array}{l}\text { Log of urine LL-37 } \\
\text { ng/mg creatinine }\end{array}$} \\
\hline & Coefficient & SE & $P$ & Coefficient & SE & $\mathrm{P}$ \\
\hline Age & -0.002 & 0.001 & 0.113 & 0.000 & 0.002 & 0.986 \\
\hline Male gender & -0.093 & 0.040 & 0.022 & -0.109 & 0.059 & 0.066 \\
\hline TWBCs & 0.018 & 0.008 & 0.038 & -0.012 & 0.013 & 0.358 \\
\hline Neutrophils & -0.001 & 0.006 & 0.893 & -0.001 & 0.007 & 0.913 \\
\hline Lymphocytes & -0.001 & 0.006 & 0.812 & -0.004 & 0.007 & 0.596 \\
\hline Basophiles & 0.001 & 0.008 & 0.933 & -0.007 & 0.010 & 0.513 \\
\hline Urinary tract infections & 0.153 & 0.045 & 0.001 & 0.162 & 0.077 & 0.038 \\
\hline Plasma LL-37 ng/ml & - & - & - & 0.238 & 0.019 & $<0.001$ \\
\hline
\end{tabular}

Our findings provide the first evidence in adult and young children of both genders that the level of LL-37 correlates with positive urine culture in cases of urinary infections. Furthermore, LL-37 levels can be used as a marker of infection and could save time in confirming an accurate diagnosis of UTI in the acute phase. The ability to make an early decision about whether there is an infection or not and would be helpful in limiting unnecessary antimicrobial administration for suspected urinary infections, see Fig. 2. In turn, this would decrease health care costs and the problems associated with inappropriate use of antibiotics. Our results demonstrated differences in plasma and urinary levels of LL-37 between subjects with and without UTIs. To the

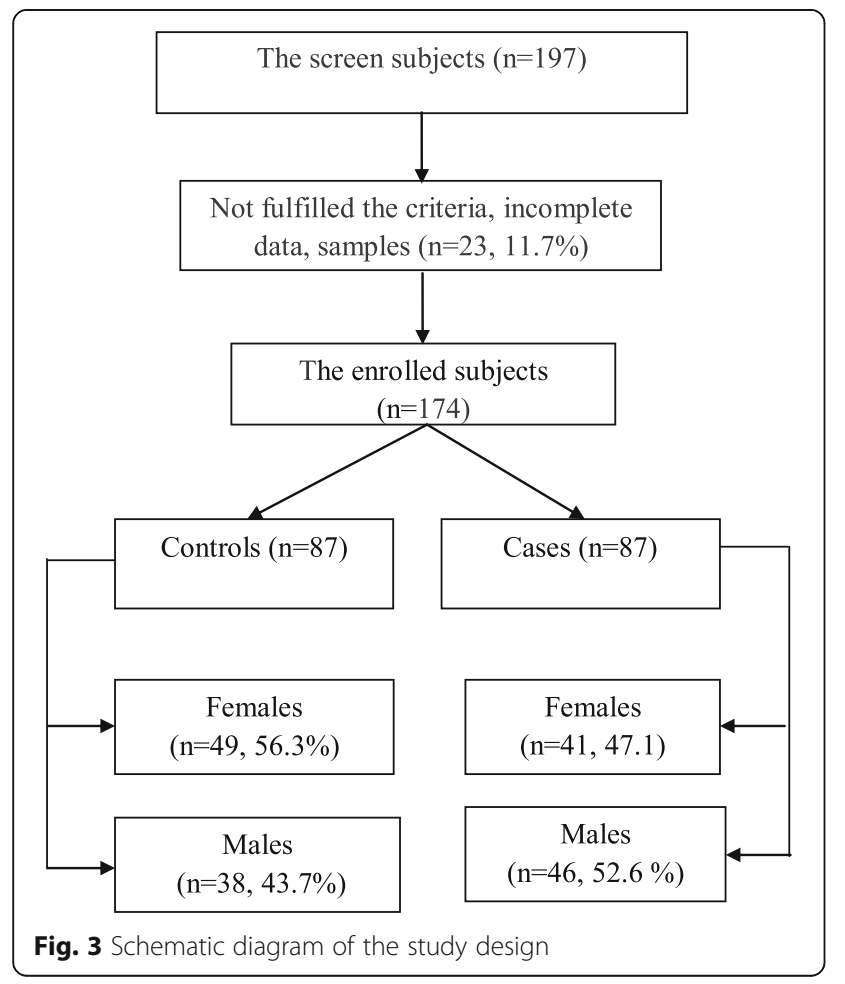

best of our knowledge, this is the first study performed in apparently healthy and non-hospitalized controls that compares their plasma and urine LL-37 levels with patients (both genders) with UTIs. Additionally, this is the first study to compare inter-individual baseline plasma and urine LL-37 levels for patients and for controls. Table 2, Figs. 1a and b and 3.

In the current study there was no significant difference in both plasma and urine LL-37 levels when comparing isolates of E. coli and other uropathogens. This indicates that the microbial infection increases the levels of LL-37 in both plasma and urine concurrently.

To determine the exact circulating level of LL-37 in plasma in relation to UTIs further research needs to be conducted. Studies with much larger subject numbers are required. The limitation of the current study; there was no follow-up sampling to detect LL-37 level after clearance of infection.

\section{Conclusion}

Infection of the urinary tract increases the levels of LL-37. The observed increased level was not only in the patient's urine, but has also been observed in the plasma of patients during the period of infection of the urinary tract. Detection of increased levels of LL-37 could help to differentiate subjects with suspected UTI. Accordingly, LL-37 could act as a good marker for diagnosing UTIs.

\footnotetext{
Abbreviations

(>): Greater than; $(\geq)$ : Greater than or equal; $\left({ }^{\circ} \mathrm{C}\right)$ : Degrees Celsius; (Camp-/-): CRAMP-deficient; (Camp+/+): CRAMP-producing; ( $=$ =): P-value; $(r=)$ : Correlation; (slgA): Secretory IgA antibodies; (vs): Versus; AMPs: Antimicrobial peptides; AST: Antibiotic sensitivity test; AST-N: Gram negative antibiotic sensitivity card; CAMP: Cathelicidin gene; CBC: Complete blood count; CFU/ml: Colony-forming unit per milliliter; CLED: Cysteine lactose electrolyte deficient; CRAMP: Cathelin-related antimicrobial peptide; $E$. coll: Escherichia coli; E. faecalis: Enterococcus faecalis; EDTA: Ethylene-diaminetetra-acetic acid; ELISA: Enzyme-linked immunosorbent assay; GN card: Gram negative identification card; GP card: Gram positive ID card; GP/AST: Gram positive antibiotic sensitivity card; Greater than; hCAP-18: Human cationic antimicrobial peptide-18; ID card: Identification card; K. pneumoniae: Klebsiella pneumoniae; kD: Kilodalton; LL-37: Cathelicidin; LPS: Lipopolysaccharides; M. morganii: Morganella morganii; MIC: Minimum inhibitory concentrations; ng/
} 
ml: Nanograms per milliliter; P. aeruginosa: Pseudomonas aeruginosa; $P$. mirabilis: Proteus mirabilis; SPSS: Statistical package for the social sciences; Ucr: urinary creatinine; UPEC: Uropathogenic E. coli; UTI: Urinary tract infection; V2C: VITEK-2 Compact System; WBC: White blood cell; $x^{2}$ : Chi-Square

\section{Acknowledgements}

The authors are very grateful to all the patients and healthy control participants for their participation in the study.

\section{Funding}

We would like to confirm that there was no funding for this study.

\section{Availability of data and materials}

All the data supporting our findings are contained within this work; any other datasets used and/or analyzed during the current study are available from the corresponding author on reasonable request.

\section{Authors' contributions}

$I B$ and EAA carried out the study and participated in drafting the manuscript. $\mathrm{NB}, \mathrm{AA}$, and EEA participated in designing the study and participated in drafting the manuscript. IB carried out the laboratory work. IA coordinated and participated in designing the study, statistical analysis and drafting the manuscript. All the authors read and approved the final version.

\section{Ethics approval and consent to participate}

Institutional review board approval was obtained from the Faculty of Medical Laboratory Sciences Research Ethics Review Board, University of Khartoum, Sudan. A signed written informed consent was obtained from all subjects. For participants under the age of 16 years their parents or guardian on behalf signed written consents after being informed about the study.

\section{Consent for publication}

Not applicable.

\section{Competing interests}

The authors declare that they have no competing interests.

\section{Publisher's Note}

Springer Nature remains neutral with regard to jurisdictional claims in published maps and institutional affiliations.

\section{Author details}

${ }^{1}$ College of Medical Laboratory Sciences, Microbiology Department, University of Khartoum, Khartoum, Sudan. ${ }^{2}$ Faculty of Medical Laboratory Sciences, University of Science and Technology, Omdurman, Sudan. ${ }^{3}$ Khartoum University Central Research Laboratory, University of Khartoum, PO Box 321, Khartoum, Sudan. ${ }^{4}$ College of Medicine, Qassim University, Buraydah, Qassim, Kingdom of Saudi Arabia.

Received: 1 March 2017 Accepted: 10 December 2017

Published online: 08 January 2018

\section{References}

1. Spencer JD, Schwaderer AL, Becknell B, Watson J, Hains DS. The innate immune response during urinary tract infection and pyelonephritis. Pediatr Nephrol. 2014;29(7):1139-49.

2. Kucheria R, Dasgupta P, Sacks S, Khan M, Sheerin N. Urinary tract infections: new insights into a common problem. Postgrad Med J. 2005:81(952):83.

3. Stapleton A. Prevention of recurrent urinary-tract infections in women. Lancet. 1999;353(9146):7-8.

4. Zanetti M, Gennaro R, Skerlavaj B, Tomasinsig L, Circo R. Cathelicidin peptides as candidates for a novel class of antimicrobials. Curr Pharm Des. 2002:8(9):779-93.

5. Matejuk A, Leng Q, Begum M, Woodle M, Scaria P, Chou S, et al. Peptidebased antifungal therapies against emerging infections. Drugs Future. 2010; 35(3):197.

6. Minardi D, d'Anzeo G, Cantoro D, Conti A, Muzzonigro G. Urinary tract infections in women: etiology and treatment options. Int J Gen Med. 2011;4:333-43.

7. Kumar V, Abbas AK, Aster JC. Robbins basic pathology: Elsevier health sciences; 2012
8. Ragnarsdóttir B, Lutay N, Grönberg-Hernandez J, Köves B, Svanborg C Genetics of innate immunity and UTI susceptibility. Nat Rev Urol. 2011;8(8): 449-68.

9. Song J, Abraham S. Innate and adaptive immune responses in the urinary tract. Eur J Clin Investig. 2008;38(s2):21-8.

10. Foxman B. The epidemiology of urinary tract infection. Nat Rev Urol. 2010; 7(12):653-60.

11. Zasloff M. Antimicrobial peptides of multicellular organisms. Nature. 2002; 415(6870):389-95

12. Ganz T. Defensins: antimicrobial peptides of innate immunity. Nat Rev Immunol. 2003;3(9):710-20.

13. Tomasinsig L, Zanetti M. The cathelicidins-structure, function and evolution. Curr Protein Pept Sci. 2005;6(1):23-34.

14. Sorensen $O E$, Follin $P$, Johnsen $A H$, Calafat J, Tjabringa GS, Hiemstra PS, et al Human cathelicidin, hCAP-18, is processed to the antimicrobial peptide LL37 by extracellular cleavage with proteinase 3. Blood. 2001;97(12):3951-9.

15. Zaiou M, Nizet V, Gallo RL. Antimicrobial and protease inhibitory functions of the human cathelicidin (hCAP18/LL-37) prosequence. J Investig Dermatol. 2003:120(5):810-6.

16. Agerberth B, Charo J, Werr J, Olsson B, Idali F, Lindbom L, et al. The human antimicrobial and chemotactic peptides LL-37 and a-defensins are expressed by specific lymphocyte and monocyte populations. Blood. 2000; 96(9):3086-93.

17. Larrick JW, Hirata M, Balint RF, Lee J, Zhong J, Wright SC. Human CAP18: a novel antimicrobial lipopolysaccharide-binding protein. Infect Immun. 1995; 63(4):1291-7.

18. Nagaoka I, Hirota S, Niyonsaba F, Hirata M, Adachi Y, Tamura H, et al. Augmentation of the lipopolysaccharide-neutralizing activities of human cathelicidin CAP18/LL-37-derived antimicrobial peptides by replacement with hydrophobic and cationic amino acid residues. Clin Diagn Lab Immunol. 2002;9(5):972-82

19. Suzuki K, Murakami T, Kuwahara-Arai K, Tamura H, Hiramatsu K, Nagaoka I. Human anti-microbial cathelicidin peptide LL-37 suppresses the LPSinduced apoptosis of endothelial cells. Int Immunol. 2011:23(3):185-93.

20. Kandler K, Shaykhiev R, Kleemann P, Klescz F, Lohoff M, Vogelmeier C, et al. The anti-microbial peptide LL-37 inhibits the activation of dendritic cells by TLR ligands. Int Immunol. 2006;18(12):1729-36.

21. Becknell B, Schwaderer A, Hains DS, Spencer JD. Amplifying renal immunity: the role of antimicrobial peptides in pyelonephritis. Nat Rev Nephrol. 2015; 11(11):642-55.

22. Zanetti M. Cathelicidins, multifunctional peptides of the innate immunity. J Leukoc Biol. 2004;75(1):39-48.

23. Zanetti M. The role of cathelicidins in the innate host defenses of mammals. Curr Issues Mol Biol. 2005;7(2):179-96.

24. Reddy K, Yedery R, Aranha C. Antimicrobial peptides: premises and promises. Int J Antimicrob Agents. 2004;24(6):536-47.

25. Andres E, Dimarcq J. Cationic anti-microbial peptides: from innate immunity study to drug development. Rev Med Interne. 2004;25(9):629-35.

26. Zasloff M. Antimicrobial peptides, innate immunity, and the normally sterile urinary tract. J Am Soc Nephrol. 2007;18(11):2810-6.

27. Underdown BJ, Schiff JM. Immunoglobulin A: strategic defense initiative at the mucosal surface. Annu Rev Immunol. 1986;4(1):389-417.

28. Hamdan HZ, Ziad AHM, Ali SK, Adam I. Epidemiology of urinary tract infections and antibiotics sensitivity among pregnant women at Khartoum North Hospital. Ann Clin Microbiol Antimicrob. 2011:10(1):2.

29. Hamdan HZ, Kubbara E, Adam AM, Hassan OS, Suliman SO, Adam I. Urinary tract infections and antimicrobial sensitivity among diabetic patients at Khartoum, Sudan. Ann Clin Microbiol Antimicrob. 2015;14(1):26.

30. Chromek M, Slamova Z, Bergman P, Kovacs L, Podracka L, Ehren I, et al. The antimicrobial peptide cathelicidin protects the urinary tract against invasive bacterial infection. Nat Med. 2006;12(6):636-41.

31. Chromek M, Brauner A. Antimicrobial mechanisms of the urinary tract. J Mol Med. 2008;86(1):37-47

32. Nielsen $\mathrm{KL}$, Dynesen $\mathrm{P}$, Larsen $\mathrm{P}$, Jakobsen L, Andersen PS, Frimodt-Møller $\mathrm{N}$. Role of urinary cathelicidin LL-37 and human $\beta$-defensin 1 in uncomplicated Escherichia coli urinary tract infections. Infect Immun. 2014; 82(4):1572-8

33. Ali AS, Townes $\mathrm{CL}$, Hall J, Pickard RS. Maintaining a sterile urinary tract: the role of antimicrobial peptides. J Urol. 2009;182(1):21-8.

34. Övünç HD, Altun D, Hacıhamdioğlu B, Cekmez F, Aydemir G, Kul M, et al. The association between serum 25-Hydroxy vitamin D level and urine 
cathelicidin in children with a urinary tract infection. J Clin Res Pediatr Endocrinol. 2016;8:325.

35. Norden CW, Green GM, Kass EH. Antibacterial mechanisms of the urinary bladder. J Clin Investig. 1968:47(12):2689.

36. Bates JM, Raffi HM, Prasadan K, Mascarenhas R, Laszik Z, Maeda N, et al. Tamm-Horsfall protein knockout mice are more prone to urinary tract infection rapid communication. Kidney Int. 2004;65(3):791-7.

37. Fliedner M, Mehls O, Rauterberg E-W, Ritz E. Urinary slgA in children with urinary tract infection. J Pediatr. 1986;109(3):416-21.

38. Abrink M, Larsson E, Gobl A, Hellman L. Expression of lactoferrin in the kidney: implications for innate immunity and iron metabolism. Kidney Int. 2000;57(5):2004-10.

39. Morrison G, Kilanowski F, Davidson D, Dorin J. Characterization of the mouse beta defensin 1, Defb1, mutant mouse model. Infect Immun. 2002; 70(6):3053-60

40. Valore EV, Park CH, Quayle AJ, Wiles KR, McCray PB Jr, Ganz T. Human beta-defensin-1: an antimicrobial peptide of urogenital tissues. J Clin Investig. 1998;101(8):1633.

41. Mulvey MA, Lopez-Boado YS, Wilson CL, Roth R, Parks WC, Heuser J, et al. Induction and evasion of host defenses by type 1-piliated uropathogenic Escherichia coli. Science. 1998;282(5393):1494-7.

\section{Submit your next manuscript to BioMed Central} and we will help you at every step:

- We accept pre-submission inquiries

- Our selector tool helps you to find the most relevant journal

- We provide round the clock customer support

- Convenient online submission

- Thorough peer review

- Inclusion in PubMed and all major indexing services

- Maximum visibility for your research

Submit your manuscript at www.biomedcentral.com/submit 